\title{
JAH Forum
}

\section{REIMAGINING THE AFRICAN-ATLANTIC ARCHIVE: METHOD, CONCEPT, EPISTEMOLOGY, ONTOLOGY*}

\author{
James H. Sweet \\ University of Wisconsin-Madison
}

\begin{abstract}
For many scholars, the history of Africans in the Atlantic world only becomes visible at the juncture of the history of 'the slave'. However, the sources upon which most of these studies are based, and the organization of the colonial archive more generally operate as something of a trap, inviting researchers to see how African slaves embraced or manipulated colonial institutions and ideas for their own purposes. This article focuses on methodological and conceptual meta questions that challenge how historians conduct African-Atlantic history, arguing that sources of the African past exist in the Americas, if only we are open to seeing them.
\end{abstract}

\section{Key Words}

African diaspora, Central Africa, slavery, method.

In the mid-seventeenth century, German traveler Zacharias Wagener produced a painting entitled 'Negertanz' (Black Dance), depicting a group of Africans engaged in what appears to be some form of dancing and merry making in northeast Brazil. ${ }^{\mathrm{I}}$ When I first encountered this image, shortly after completing the manuscript for my first book, I knew right away that there was much more going on than the terse title would indicate. I had recently completed several years of archival research in which I had come across dozens of descriptions of Central African healing rituals known as 'calundu'. The typical calundu was much like the one performed by an enslaved woman named Caterina in Bahia in the r68os. Caterina was renowned for curing 'ulundus', which she said were 'her relatives who died in Angola, her homeland'. Caterina cured other slaves who suffered from a variety of ailments. In order to draw the spirits of her deceased ancestors to take possession of her body, Caterina ordered singing and dancing to the sounds of musical instruments known as canzas (scrapers) and tabaques (drums). Though apparently not the case with Caterina's ritual, in some instances a fermented alcoholic beverage known as alua was used to lubricate the proceedings. The ancestral spirit soon mounted Caterina and she

\footnotetext{
* Author's email: jhsweet@wisc.edu

I Zacharias Wagener, 'Negertanz', Thier Buch, plate I05, Staatliche Kunstsammlungen, Kupferstich-Kabinett, Dresden, Germany.
} 
fell to the ground 'like a dead person'. As she entered her possessed state, she was dressed in the skins of wild animals and anointed on the face with white clay known as mpemba. The spirit then used Caterina's body as a medium to speak in the language of her homeland. Caterina's Angolan ancestor divined the causes of illnesses and proffered remedies to her clients, prompting Caterina to go off into the woods to search for the roots and herbs that would heal them. ${ }^{2}$

Though the details of this case, and many others like it, closely matched the content of the Wagener painting, this was not the only thing that convinced me that the German traveler observed more than a simple 'dance'. In the seventeenth century, roughly 690,000 African slaves arrived in Brazil from the Kongo/Angolan region, representing 88 per cent of all African arrivals. ${ }^{3}$ Meanwhile, only around a hundred thousand Portuguese immigrated to the colony. ${ }^{4}$ Despite this preponderance of Central Africans in the immigrant population of Brazil, few scholars had seriously considered their impact on the colony. For me, it seemed only logical to read the Wagener painting through the lens of Central Africa, and I ultimately concluded that what Wagener actually recorded was calundu. Given the weight of the evidence, these were relatively easy conclusions to reach. By reading the painting through the lens of Angolan divination and healing, one can see the durability of a distinct Central African therapeutic system in Brazil's African and African-descended communities. But what was the broader impact of Central Africans, and Africans more generally? Did Africans make larger, more enduring contributions to colonial Brazilian and Atlantic history? How can we 'read' Atlantic histories through an African lens, and how would these histories be transformed through such a reading?

It has become almost banal to recite the fact that between I 500 and 1820 , more than three out of four immigrants to the Americas were Africans. ${ }^{5}$ Yet, for many scholars, the history of Africa and Africans in the Atlantic world only becomes visible at its juncture with the history of 'the slave'. On some level, this makes perfect sense. After all, our knowledge about early African-Atlantic history derives largely from European sources relating to slaving and slaves. We know a tremendous amount about the trade in African slaves, the labor of African slaves, the Christianization of African slaves, and even African slave contributions to revolutionary and emancipationist movements. To be sure, this scholarship has provoked stimulating debates. However, the sources upon which most of these studies are based, and the organization of the colonial archive more generally, operate as something of a trap, inviting researchers to see how 'slaves' embraced or manipulated colonial institutions and ideas for their own purposes. In this way, African-Atlantic history often begins with American history - utilizing the same basic chronologies, same watershed

2 Arquivo Nacional da Torre do Tombo, Lisboa, Inquisição de Lisboa, Cadernos do Promotor, No. 67, Livro 26I, ff. 3II-320v. (quotes 3I8v.).

3 Estimate Table, 'Assessing the Slave Trade', Voyages: The Trans-Atlantic Slave Trade Database, (http://www. slavevoyages.org/tast/assessment/estimates.faces), accessed 8 February 2014.

4 A. J. R. Russell-Wood, The Portuguese Empire, I4I5-I80o: A World on the Move (Baltimore, MD, I998), $6 \mathrm{I}-2$.

5 D. Eltis, 'Free and coerced migrations from the Old World to the New', in D. Eltis (ed.), Coerced and Free Migration: Global Perspectives (Stanford, CA, 2002), 36. 
moments, and same emphases on European institutions and ideas-reducing the African-Atlantic experience to the history of the slave.

One powerful and provocative example of the trend toward conflating African history with the history of slavery in colonial America is the continuing emphasis on 'Atlantic creoles'. In nearly all of these formulations, scholars view African history from a peculiarly Euro-American perspective in which Africans become progressively more European in language, dress, religion, and political outlook. Thus, cultural change is bound to the colonizing Atlantic world, the process of Americanization beginning in Africa itself. Though the intents of these scholars are informed by very 'postcolonial' imperatives that seek to empower Africans in an Atlantic context, the result is often something that seems to me far more imperial. To suggest that European lifeways acted as fundamentally transformative for those who would become enslaved is not only to exaggerate European impacts in Africa; it also reifies the notion that African-American culture begins with European forms. For example, in Ira Berlin's formulation, Atlantic creoles were composed of 'cosmopolitan men and women of African descent ... . Their knowledge of the larger Atlantic World, the fluidity with which they moved in it, and their chameleon-like ability to alter their identity moderated the force of chattel bondage ... . [These] Atlantic creoles found themselves very much at home in their new environment. ${ }^{6}$ More recently, John Thornton and Linda Heywood argue that Atlantic creole knowledge of European culture, especially Christianity, 'made it easy for them to integrate into the colonial environment'. ${ }^{7}$ In these renderings, the African embrace of European culture appears thoroughgoing - in education, in religion, in cosmopolitan savvy, such that slaves in early North America are practically indistinguishable from their masters.

The argument that 'Atlantic creoles' were representative of the earliest generations of African slaves in North America is now a standard narrative in introductory American history courses and has also gained traction in the historiographies of the Caribbean and Brazil. ${ }^{8}$ Perhaps more tellingly, it has received widespread popular currency in television documentaries like PBS's 'Slavery and the Making of America' (2004) and in prominent public museums. At the 75,000 square foot Jamestown Settlement museum, which opened in 2007 in celebration of 400 years of Virginia history, the cultural practices of seventeenth-century Central Africans are represented as primarily Christian. Indeed, the centerpiece of this portion of the exhibit is an eighteenth-century Kongolese crucifix. There is also an evocative 23-minute movie, filmed on location in Luanda, depicting the enslavement of a young woman named Angela. Angela eventually becomes one of the 'twenty and odd' Africans to arrive in Jamestown in I6I9, after English privateers

6 I. Berlin, Generations of Captivity: A History of African-American Slaves (Cambridge, MA, 2003), 6 and 32.

7 L. M. Heywood and J. K. Thornton, Central Africans, Atlantic Creoles, and the Foundation of the Americas, I585-I660 (New York, 2007), 2. Later, at page 282, Thornton and Heywood reiterate, 'Being Atlantic Creole, and especially being Christian ... made it easier for them to prosper and to feel comfortable in the world of European settlers.'

8 For the Caribbean, see J. Landers, Atlantic Creoles in the Age of Revolutions (Cambridge, MA, 20IO); and J.F. Sensbach, Rebecca's Revival: Creating Black Christianity in the Atlantic World (Cambridge, MA, 2005). For Brazil, see C. F. da Silva Júnior, 'Tráfico, traficantes e agentes na Bahia setecentista', Revista de História UFBA, I:I (2009), 37-52 (citing Berlin on 46); and more directly, R. Price, 'O milagre da crioulização: retrospectiva', Estudos Afro-Asiáticos, 25:3 (2003), 383-4I9. 
take her from a Portuguese slave ship captured in the Caribbean. In the film, Portuguese slave traders receive the blessing of a Jesuit priest at the cathedral in Luanda. Meanwhile, Angela pounds grain in her small village along the Kwanza River. Finally, Angela is captured and marched to the beach. At the conclusion of the film, as she boards the Portuguese slave ship, the Jesuit priest asks Angela if she has been baptized. She answers 'yes', and the priest responds, 'Then she is a child of God. When she dies she will go to heaven.' The slave ship then sets sail into a radiant sunset on the western Atlantic horizon. The message of the film is unambiguous: regardless of her temporal fate, Angela will be eternally redeemed by her Christian faith. That is all the viewer needs to know. There is no depiction of what this Christian faith entails. Worse still, silenced are the horrors of the Middle Passage and slavery in the Americas - the very experiences that might have caused her to question her faith. The viewer is left to assume that a familiar Christianity served as a protective balm against the suffering of slavery in the Americas.

This elemental, buffet-style approach to the African past, however well intentioned, precludes a serious engagement with African history. Here, creolization becomes an ossified Atlantic 'thing' rather than an open, complex, multifaceted 'process'. Indeed, one of the implicit suggestions of histories focused on 'Atlantic creoles' is that there were 'pure' or homogenous groups of African peoples who acted as a counterpoint to those inflected with European blood and culture. Even in those studies where the African past is rendered more complex, there is still a tendency to anticipate European-Atlantic creolization as the 'real' beginning of history. Thus, in his study of the rise of the slave trade in Upper Guinea, Toby Green describes the spread of Mandinka influences across the region in the fourteenth and fifteenth centuries as 'primary creolisation', a 'foretaste' of the 'Atlantic creole' cultures to which he devotes three-quarters of his book. For Green, as with so many others, the concept of creolization is 'inseparable' from the study of Atlantic slavery, bound to a teleology of historical change that is ultimately dependent on Europeans. ${ }^{9}$

This narrow, European-Atlantic approach to creolization operates in crucial dialogue with major conceptual watersheds that have defined professional, academic African history for the past fifty years. Nowhere is this clearer than in the periodization that defines the African past as 'precolonial', 'colonial', and 'postcolonial'. At the juncture of Atlanticist and Africanist approaches, European-African exchanges are given primacy as the motive force of history, while the deep African past is often reduced to a flattened, static 'prehistory'. Atlantic approaches might appear to offer 'precolonial' Africans 'history', but only through the outward-looking prism of European influences, almost always mediated through the colonial archive. These approaches largely ignore archaeology, material history, environmental history, historical linguistics, oral traditions, and other crucial methodologies. As a result, intra-African histories are often obscured. ${ }^{\text {IO }}$ Even so-called revisionist histories of the African diaspora start from the premise of eventual

9 T. Green, The Rise of the Trans-Atlantic Slave Trade in Western Africa, I300-I589 (Cambridge, MA, 20I2), I3 and 57 .

Io There are crucial exceptions; see for example, R. M. Baum, Shrines of the Slave Trade: Diola Religion and Society in Precolonial Senegambia (New York, I999); E. L. Fields-Black, Deep Roots: Rice Farmers in West Africa and the African Diaspora (Bloomington, IN, 2008); W. Hawthorne, Planting Rice and Harvesting Slaves: Transformations along the Guinea-Bissau Coast, I400-I900 (Portsmouth, NH, 2003); 
European-African exchange, albeit with greater attention to African politics and cultures, most often framed as resistance to European slavery. In this way, 'precolonial' West African history often gets collapsed into the Atlantic. The explosion of Atlantic approaches has thus contributed to perceptions of 'crisis' or even the 'death' of scholarship on the deep history of Africa, though that demise seems to be greatly exaggerated, especially outside of the Atlantic vortex. Perhaps the only real crisis in early African history exists at the juncture of the 'precolonial', the Atlantic, and the slave. ${ }^{\text {II }}$

The best way to break this bottleneck of European logics is to reject 'precolonial', 'Atlantic', and 'slave' as the primary framing devices for scholarly inquiry into the African past. These simply aren't useful starting points in the complex, fluid histories of African peoples. ${ }^{\mathrm{I} 2}$ Lisa Lindsay aptly points to the relationship between the economy of extroversion and cultural creolization in the Atlantic slave trade, but we must be mindful that accumulation of 'outsider' knowledge, innovation, and technology drove political economies in Africa well before the arrival of peoples from beyond the continent's borders. Processes of African cultural transformation thus began not in encounters with 'the world', but through earlier, sustained histories of intra-African migration and trade, framed by overlapping hierarchies of social and political dependency. ${ }^{33}$ This is not to deny the

G. Ugo Nwokeji, The Slave Trade and Culture in the Bight of Biafra: An African Society in the Atlantic World (New York, 2010).

II On the perceived crisis in early African history, see R. Reid, 'Past and presentism: the "precolonial" and the foreshortening of African history', The Journal of African History, 52:2 (20I I), I35-55. John Thornton has also lamented the decline of precolonial African history, prompting a lively panel discussion on the topic at the African Studies Association annual meeting in Washington, D. C., November I7-I9, 20I I. Some observers at the meeting wryly noted that precolonial African history seemed to be booming, since attendance at the session was over-subscribed - people sitting on the floor - and the shared winners of the Herskovits Prize were both precolonialists. For a related critique of the periodization of African history, see N. M. Creary, 'Times of lamentation: rethinking periodization in African history', Atenea, 30:I-2 (2010), I07-17. And for a broader reflection on the 'prehistory' of Africa, see A. Ogundiran, 'The end of prehistory? an Africanist comment', American Historical Review, I I 8:3 (2013), 788-80I.

I2 It is noteworthy that while African Atlantic historiography is thriving, there is no analogous emphasis on an Amerindian Atlantic. Echoing some of the arguments I make here, Paul Cohen argues that so long as the Atlantic history paradigm is constructed around 'Eurocentric categories', it has little to offer to our understanding of the native past. Atlantic history 'needs' Amerindians, but not the other way around. P. Cohen, 'Was there an Amerindian Atlantic? reflections on the limits of a historiographical concept', History of European Ideas, 34:4 (2008), 388-4I0, esp. 400-I. For a counterpoint, see J. Weaver, The Red Atlantic: American Indigenes and the Making of the Modern World, I000-I927 (Chapel Hill, NC, 20I4).

I3 See, for example, G. L. Chouin and C.R. DeCorse, 'Prelude to the Atlantic trade: new perspectives on southern Ghana's pre-Atlantic history (800-1 500)', The Journal of African History, 5 I:2 (2010), I23-45; C. Ehret, An African Classical Age: Eastern and Southern Africa in World History, iooo B. C. to A.D. 400 (Charlottesville, VA, I998); K. A. Klieman, 'The Pygmies Were Our Compass': Bantu and Batwa in the History of West Central Africa, Early Times to c. I900 C.E. (Portsmouth, NH, 2003); N. Kodesh, Beyond the Royal Gaze: Clanship and Public Healing in Buganda (Charlottesville, VA, 2010); A. O. Ogundiran, Archaeology and History in İlàrè District (Central Yorubaland, Nigeria), I200-I900 A.D. (London, 2002); D. L. Schoenbrun, A Green Place, a Good Place: Agrarian Change, Gender, and Social Identity in the Great Lakes Region to the $15^{\text {th }}$ Century (Portsmouth, NH, I998); D. L. Schoenbrun, 'Conjuring the modern in Africa: durability and rupture in histories of public healing between the Great Lakes of East Africa', American Historical Review, III:5 (2006), I403-39; J. Vansina, Paths in the Rainforests: Toward a History of Political Tradition in Equatorial Africa (Madison, WI, I990); and J. Vansina, How Societies Are Born: Governance in West Central Africa before I60o (Charlottesville, VA, 2004). 
importance of European arrivals and the transformation of Africa's political economy. Rather, it is a plea to frame those transformations more explicitly as extensions of earlier historical processes. To be sure, increasing European demand for slaves resulted in socially destructive predatory states, credit-poor, soba bandits, and mafia-like networks such as the Aro. While these groups derived their power largely from Atlantic markets, their victims did not sit by idly waiting to become 'slaves'. Rather, they formulated dynamic strategies for security and survival, often contesting the political legitimacy of slavers by adapting familiar sociocultural models to the new configurations of power.

Across West Africa, refugee strangers gathered around powerful figures who offered protection from slaving. In Central Africa, Kimbundu- and Kikongo-speaking refugees settled in southern Kongo in the early seventeenth century under the banner of soldiers known as ndembu. ${ }^{\mathrm{I}}$ Similarly, runaway slaves from Luanda fled to the southern region of Kisama, where they rallied around a series of militarized sobas known as Kafuxi Ambari, who protected them from Portuguese raids. ${ }^{5}$ The emergence of the asafo companies among the Fante, mentioned by Lindsay, are yet another example of the kinds of warrior communities that challenged predatory states. In other instances, refugees from slaving gathered around powerful healers who promised redemption from famine, disease, and other symptoms wrought by illegitimate states. In eighteenth-century Benin, therapeutic communities formed around vodun priests like Domingos Álvares, whose devotion to the earth deity Sakpata was interpreted as a threat to the Dahomean monarchy. ${ }^{\mathrm{I}}$ These new communities of refugee strangers followed many of the hierarchies of dependency and patterns of reciprocity that characterized African societies prior to the rise of the Atlantic slave trade, stressing the health and prosperity of the group (including ancestors and spirits) over individual accumulation and wealth. In the cases of the Gold Coast and central Benin, entirely new 'confederations' emerged - the Fante and the Mahi-that owed their political existence to their opposition to predatory states. ${ }^{\mathrm{I} 7}$

Ultimately, then, I agree with Lindsay that the political economy of extroversion shaped creolization and vice versa; however, my emphasis rests far less on the ways African slavers embraced Atlantic markets and European tastes than on the ways peoples displaced from their ancestral homelands adapted earlier political models to address the new challenges wrought by slaving and social disintegration. It is no coincidence that asafo, ndembu, kisama, mahi, and vodun all (re)appear in various 'slave' communities of the Americas. The continuation of these ideas in the Atlantic world was never so much about 'slave culture' as it was a sign of durable African politics. In the same ways that alienated, displaced

\footnotetext{
I4 J. C. Miller, 'Central Africa during the era of the slave trade, c. I490s-I85os', in L. M. Heywood (ed.), Central Africans and Cultural Transformations in the American Diaspora (Cambridge, MA, 2002), 46-7.

I 5 J. Krug, "“They glorify in a certain independence”: the politics of identity in Kisama, Angola, and its diasporas in the sixteenth and seventeenth centuries' (unpublished PhD thesis, University of Wisconsin, 20I2).

I6 J. H. Sweet, Domingos Álvares, African Healing, and the Intellectual History of the Atlantic World (Chapel Hill, NC, 20II).

I7 On Fante, see R. Shumway, The Fante and the Transatlantic Slave Trade (Rochester, NY, 20 I I). On Mahi, see S. Anignikin, 'Histoire des populations mahi: à propos de la controverse sur l'ethnonyme et le toponyme “Mahi”, Cahiers d'Études Africaines, 4I:I62 (200I), 243-65; and Sweet, Domingos Álvares, I4-26.
} 
peoples in West Africa constructed moral communities that challenged slaving, so too did Africans in the Americas. ${ }^{\text {I }}$

What I am suggesting here is something that may seem painfully obvious: creolization is not a historical process that is exceptionally American or Atlantic; it is a process born out of social rupture, alienation, and the constant striving for new communities of belonging. By remaining bound to European colonial logics, scholars ignore the thousands of Africans who operated at the boundaries of European ideas and institutions - those who barely, if ever, learned European languages, customs, or ways of being. Once we get past the conceptual roadblock of creolization as Americanization, we can better understand why Kimbundu, and not Portuguese, was the lingua franca of slave communities in seventeenthcentury Brazil. And we can also understand why calundu, and not 'African Christianity', was a primary source of spiritual succor for enslaved and freed Africans in seventeenthcentury Brazil, eighteenth-century St Domingue, and even the nineteenth-century United States. ${ }^{\text {I9 }}$ Perhaps more importantly, we can begin to see the possibility that African ideas and political cultures 'colonized' Europeans and Native Americans just as readily as the other way around. ${ }^{20}$

Brazil is an obvious starting point for 'thinking' processes of African historical change in the Americas, but is by no means the only place. Many are no doubt familiar with the rich historiography describing how slaves in St Domingue built upon revolutionary ideologies of the Atlantic world in order to overthrow their French masters. Yet we know little about the ideas or inspirations of the majority of those slaves. Roughly two-thirds were Africans, half of whom had arrived in St Domingue in the five years leading up to the revolution. ${ }^{2 I}$ And the majority of those Africans hailed from Kongo and Angola. ${ }^{22}$ Surely the history of the Haitian revolution cannot be reduced to its US and French intellectual equivalencies. Though some scholars have provocatively suggested that the Haitian revolution was an African revolution, the intellectual and political imperatives of these Africans are still only scarcely understood for this most African of Atlantic revolutions. ${ }^{23}$

I 8 The immediate inspiration for these ideas about the durability of political language across time and space comes from Schoenbrun, 'Conjuring the modern in Africa', building on the pioneering work of Steven Feierman, Wyatt MacGaffey, and others.

I9 See J.H. Sweet, 'The evolution of ritual in the African diaspora: Central African Kilundu in Brazil, St Domingue, and the United States, seventeenth-nineteenth centuries', in M. A. Gomez (ed.), Diasporic Africa: A Reader (New York, 2006), 64-80.

20 See, for example, the promising work of J. Elrick, 'Black religions with white faces: the creolization of religious belief and practice in colonial Angola, Brazil, and Cuba, I600-I 889' (unpublished PhD thesis, Vanderbilt University, 2013).

2 I St. Domingue's slave population approached 500,000 by I79I, representing about 90 per cent of the colony's total population. Estimates that two-thirds were Africans come from C. E. Fick, The Making of Haiti: The Saint Domingue Revolution from Below (Knoxville, TN, I990), 25. The Trans-Atlantic Slave Trade Database indicates that I69,800 Africans disembarked in St Domingue between I786 and I790, (http:// slavevoyages.org/tast/assessment/estimates.faces? yearFrom $=\mathrm{I} 760$ \&yearTo $=\mathrm{I} 790$ \& disembarkation $=40 \mathrm{I}$ ), accessed 2 I March 20I4.

22 From I760 until the outbreak of the Haitian revolution, 53 per cent of St Domingue's slaves came from West Central Africa. Trans-Atlantic Slave Trade Database, (http://slavevoyages.org/tast/assessment/estimates.faces? yearFrom=I 760\&yearTo=I790\&disembaraktion=40I, (accessed 2I March 20I4).

23 On the Haitian revolution as an African revolution, see L. Dubois, Avengers of the New World: The Story of the Haitian Revolution (Cambridge, MA, 2004), 5. For the handful of attempts to frame the Haitian 
While Brazil and St Domingue - along with Jamaica, Cuba, and parts of the US South might be more accurately understood as African societies in the years leading up to I 820 , we are still left with the formidable challenge of how to demonstrate processes of intraAfrican acculturation and exchange, especially given the consistent erasure of Africans from the European colonial archive. One way of teasing African histories and meanings out of the archive is through a more capacious methodological approach to the documents themselves. Africanist historians have utilized the smallest splinters of evidence from archaeology, historical linguistics, oral traditions, and material culture to weave together infinitely plausible, yet provisional histories of early Africa. ${ }^{24}$ These same sources of the African past exist in American archives, if only we open our eyes to them. Language is the most obvious starting point. Colonial documents are chock full of Africanlanguage terms that are easily overlooked or ignored-Kimbundu in seventeenth-century New Granada and Brazil, Twi/Akan in eighteenth-century Suriname, Kikongo in prerevolutionary Haiti, and Yoruba in nineteenth-century Cuba and north-east Brazil. These words and ideas appear most vividly in ritual descriptions found in diaries, travel accounts, court cases, and ecclesiastical records, but also in dictionaries/grammars, people's names, place names, and so on. ${ }^{25}$ Even the newspapers and journals of early modern Europe sometimes reproduced African-language dialogues in their pages. ${ }^{26}$ That these words and ideas were so easily naturalized to American and European documents should prompt us to

Revolution through an African prism, see the pioneering works of Fick, The Making of Haiti; J. K. Thornton, 'African soldiers in the Haitian revolution', Journal of Caribbean History, 25 (I99I), 58-80; J. K. Thornton, "II am the subject of the King of Congo": African political ideology and the Haitian revolution', Journal of World History, 4:2 (I993), I8I-2I4; and more recently, D. Jensen, 'Jean-Jacques Dessalines and the African character of the Haitian revolution', William and Mary Quarterly, 69:3 (20I2), 6I 5-38. See also the promising research of C.F. Mobley, 'The Congolese Atlantic: new perspectives on Central Africans in the Haitian revolution', paper delivered at the American Historical Association Conference, New Orleans, LA, January 2013.

24 Edna Bay suggests that fragments of 'collective memory' stand as 'intuitive, yet plausible' histories of precolonial Africa until these hypotheses are corroborated by new research. E. G. Bay, 'Protection, political exile, and the Atlantic slave-trade: history and collective memory in Dahomey', Slavery and Abolition, 22:I (200I), 42-60.

25 For a sample of published works that engage African languages, see L. N. Baudry des Lozières, Second voyage à la Louisiane, faisant suite au premier de l'auteur de I794 à I798, Volume 2 (Paris, I803); A. da Costa Peixoto, Obra nova de língua geral de Mina, ed. L. Silveira (Lisboa, I945 [orig. pub. I74I]); P. Dias, A arte da língua de Angola oferecida a Virgem Senhora Nossa do Rosário, mãe e senhora dos mesmos pretos (Lisboa, I697); J. Fernandez, Apostolica, y penitente vida de el V. P. Pedro Claver, de la Compañia de Iesus (Zaragoça, I666); M.L.E. Moreau de Saint-Méry, Description topographique, physique, civile, politique et historique de la partie française de l'île Saint-Domingue, 3 Volumes. (Philadelphia, PA, I797); C. G. A. Oldendorp, Geschichte der Mission der evangelischen Brüder auf den caraibischen Inseln S. Thomas, S. Croix und S. Jan (Barby, Germany, I777); A. de Sandoval, De Instauranda Aethiopum Salute (Madrid, I647 [orig. pub. I627]); J. G. Stedman, Narrative of a Five Years Expedition Against the Revolted Negroes of Surinam: Transcribed for the First Time from the Original I790 Manuscript, eds. R. Price and S. Price (Baltimore, MD, I988). For the names of individual Africans rescued from slave ships in the nineteenth century, see the African Origins Project, (http://www.african-origins.org/).

26 See, for example, the conversation between King Simão Angola and King José Mina, outlined in the Lisbon journal Folheto de Ambas Lisboas, 7 (6 October I730), Lisboa: Oficina da Música. This episode is described in fuller detail in J. H. Sweet, 'The hidden histories of African Lisbon', in J. Cañizares-Esguerra, M. D. Childs, and J. Sidbury (eds.), The Black Urban Atlantic in the Age of the Slave Trade (Philadelphia, PA, 20I3), 243-4. 
reflect on their historical meanings, both in the diaspora and in Africa. In addition to the interesting possibilities for the study of historical linguistics, these words often reveal memories and ideas that connect the diaspora to the early history of Africa. ${ }^{27}$ By tracing these ideas back to Africa, we gain valuable insights into social, political, and ritual histories, insights that can be used to fill gaps in histories drawn from oral traditions, material culture, and so on. In this way, colonial American documents offer rich possibilities for illuminating early African histories, challenging the boundaries of geographically-defined 'fields' of study and demonstrating Africa's crucial role in the modernizing Atlantic world. ${ }^{28}$

With some imagination and creativity, non-discursive, material sources can also be teased from the colonial archives. In several Portuguese Inquisition cases from the I740s, Brazilian slaves from the so-called Mina coast used metal 'pikes' as altars for divination and healing. In the documents, these pieces of iron were described as 'about one and a half feet in length with a little ball on the end made from the same iron, hollow on the inside like a cow bell'. The men who used the pikes each treated them as 'the saint of his land'. In order to sustain the saint, the men stuck the piece of iron in the ground, sprinkled cachaça over the top of it, and put the blood of chickens inside, as they proffered various chants in the 'Minna language'. ${ }^{29}$

It would have been easy to overlook the description of the object as not very meaningful, but I was curious to conjure a mental image of this iron altar. What did it actually look like? What was its significance? As it turns out, these simple iron objects, imagined from narrative descriptions in Portuguese colonial archives, opened new vistas onto the early political history of Dahomey. In the early twentieth century, French anthropologist Paul Mercier studied a Dahomean form known as asen. According to Mercier, the asen is 'a portable altar, generally made of metal. It is planted in the ground at the ceremonial location, and one pours in offering, on the plateau that crowns it, sacrificial blood and alcohol.' ${ }^{30}$ Building on the oral traditions he collected, Mercier postulated that these asen had deep historical provenance as ancestral shrines going back to the eighteenth century. Unfortunately, there were no written records prior to the nineteenth century confirming Mercier's hypothesis. ${ }^{3 \mathrm{I}}$ Only the provisional evidence of oral tradition

27 See the promising research of M. Abreu Leitão de Almeida, 'Ladinos e boçais: o regime de línguas do contrabando de africanos (I83 I-c.I850)' (unpublished MA thesis, Universidade Estadual de Campinas, 2OI2).

28 For recent examples of the ways early Central African history is illuminated by the history of the Americas, see R. A. Ferreira, Cross-Cultural Exchange in the Atlantic World: Angola and Brazil during the Era of the Slave Trade (Cambridge, MA, 20I2); and Krug, 'They glorify in a certain independence'. For similar American revelations about the histories of the Bight of Benin, see M. de Carvalho Soares, People of Faith: Slavery and African Catholics in Eighteenth-Century Rio de Janeiro (Durham, NC, 20II); M. D. Childs, An African City in the Americas: The Trans-Atlantic Slave Trade and Havana, Cuba, I762-I867 (forthcoming); K. Mann, Trans-Atlantic Lives: Slavery and Freedom in West Africa and Brazil (forthcoming); and L. N. Parés, The Formation of Candomblé: Vodun History and Ritual in Brazil (Chapel Hill, NC, 20I3).

29 Sweet, Domingos Álvares, I32-9.

30 P. Mercier, Les ase du Musée d'Abomey (Dakar, I952), 7.

3 I An anonymous Frenchman described similar iron pikes in Dahomey in an account published in I7I4. This account, only recently discovered in a French archive, is described in E. G. Bay, Asen, Ancestors, and Vodun: Tracing Change in African Art (Urbana, IL, 2008), 43-4. 
supported the argument. The description of the iron pikes in Brazilian documents not only matches Mercier's description of asen almost exactly; the cases from Brazil suggest that diviners of asen were specifically targeted for the slave trade. Dahomean oral traditions tell us that King Agaja harbored deep suspicion and fear of diviners and healers, dispatching many of them into the Atlantic world. The fact that the Dahomean monarchy eventually co-opted and monopolized the power of asen to represent the royal ancestors only underscores this likelihood.

More expansive and creative methodological approaches are important first steps in uncovering the histories of Africans in the Atlantic world; yet crucial epistemological challenges remain. As already suggested, we must set aside assumptions that Africans were simply incipient Americans who eagerly adopted European categories of meaning. Take, for example, the category of 'family', a category that most often implies biological kin-mother, father, brothers, sisters - usually within the context of a nuclear unit. In many African languages there is no specific, equivalent term for 'family'. Domingos Álvares, for example, understood family in multiple registers that cohered around ideas of 'lineage'. ${ }^{2}$ In my book, I describe the lines of reciprocity between Álvares' biological family, his ritual family, as well as deceased ancestors and voduns. Similar idioms of 'family' were utilized in French documents to describe vaudoux communities in St Domingue on the eve of the Haitian revolution. ${ }^{33}$ When Álvares appeared before the Inquisition, he claimed that his 'parents' were named Afnage and Oconon, both names associated with Sakpata initiation and worship. Portuguese documents plainly suggest that these were his natal parents (a suggestion I uncritically repeated in my book); however, Álvares very well may have understood his real 'birth' to be ritual rather than natal, thereby calling into question even the simplest conclusions drawn from the colonial archive. Whatever the case, this episode demonstrates that we must be aware of these variable categories of meaning before we can even begin to parse them from the documents.

Troubling familiar epistemological categories like 'family' helps us glimpse the ways African forms of knowledge impacted the Atlantic world, but these categories of knowledge cannot be understood separately from the ontologies that generated them. So, for example, the appearance of 'sodomites' in colonial criminal records has inspired a number of important histories centering on 'gay' or 'queer' lives. Brazilian scholars point to transvested Angolan men who had sex with other men as examples of a 'gay' subculture in the colonial world. Though politically salient today, such interpretations ultimately reinscribe categories of individual selfhood that had no meaning for these kimbanda, who defined themselves by their crucial sociopolitical roles as spirit mediums for deceased soldiers, warriors, and kings. As such, they presided over burials, consulted chiefs and kings on political affairs, and led militaries into battle. To be sure, kimbanda spirit mediums performed

32 In Kongo, too, emphasis rests on 'lineages' ( $k a n d a)$ that might include adoptees, pawns, slaves, and other dependents. W. MacGaffey, 'Lineage, structure, marriage and the family amongst the central Bantu', The Journal of African History, 24:2 (I983), I74. On the structure of the kanda, also see John K. Thornton, The Kongolese St. Anthony: Dona Beatriz Kimpa Vita and the Antonian Movement, I684-I706 (Cambridge, I998), I9.

33 See, for example, the 'vaudoux family' described by Moreau de Saint-Méry, Description topographique, Volume I, 46 and 50-I. 
temporal and spiritual penetrability as expressions of their power, but the emphasis on individual, this-worldly sexual behaviors obscures a much richer and deeper history of gender and power in Angola and the Atlantic world. By ignoring the fluid and plural ways that kimbanda embodied ancestral spirits, scholars effectively pigeonhole these men into modern, European-American (dare I say 'creolized') categories of being. Arguably, from an African perspective, the new category of 'gay' is no less discursively violent than the colonial 'sodomite'. No matter how favorably scholars spin these categories they are still constrained by categories of individual Western subjectivity, eliding fundamental expressions of African ethno-graphic selfhood. ${ }^{34}$

By advocating such ontological shifts in approaches to the study of Africans in the Atlantic world, I am keenly aware of the dangers of alterity. But alterity too has a history. In places like Brazil, St Domingue, or Jamaica, where Africans often dominated demographically and culturally, it was never so clear who constituted the 'exotic' or the 'other'. The angst of alienation, isolation, and vulnerability were widely shared in the Atlantic, albeit in varying degrees. Far from the familiar comforts of home, Europeans sometimes sought out Africans to divine the sources of illness, recover lost objects, and reveal news of friends and family abroad. In most instances, Europeans ceded the ontological domain of ancestral spirits entirely to Africans, relying on the intellectual expertise of these diviners and healers to harness African otherworldly powers. Nevertheless, sometimes Europeans adopted African forms of knowledge and ways of being as their own. By reading colonial documents through African ontological frameworks, even those sources consisting entirely of European actors might reveal something more African and, ultimately, more Atlantic, illuminating African-European historical entanglements that previous scholars have dismissed as 'superstitions', 'farces', or 'comedies'.

For example, between I7I4 and I7I8, the Frenchman, Guy le Gentil de la Barbinais, circumnavigated the globe, stopping in Salvador and Rio de Janeiro, as well as ports in Chile, Peru, and China. Barbinais's chronicle of his travels has been utilized by scholars for many years. Indeed, it was a reference in Charles Boxer's Golden Age of Brazil that recently sent me running back to Barbinais. In the process of thumbing through Nouveau Voyage, I encountered an interesting woodcut image. By itself, the woodcut seemed a bit odd, but fairly innocuous - a group of nuns playing musical instruments on a balcony and others dancing on the floor below. However, accompanying the image was a description that both shocked and delighted me. Though there is nothing in the passage that speaks explicitly to Africa, I would invite you to 'read' the description through the ontological lens of the Central African calundu ritual that began this article. In the text accompanying the woodcut Barbinais explained that in the city of Salvador, Brazil, in December I7I7:

The viceroy invited us to hear midnight mass at the Convent of Saint Claire where we attended not a comedy, but a farce. In all the religious houses of Portugal the young Mothers study during the year a certain number of foolish acts and off-color songs to perform during the night of

34 See J.H. Sweet, Recreating Africa: Culture, Kinship, and Religion in the African-Portuguese World, I44II770 (Chapel Hill, NC, 2003), 50-8; and J. H. Sweet, 'Mutual misunderstandings: gesture, gender and healing in the African Portuguese world', Past and Present, 203:4 (2009), I28-43. 
the Nativity. These women were on an open and raised platform, each one with her instrumentguitars, harps, tambourines, etc. Their director struck up his baton ... and ... all the nuns began to sing the songs they had studied with such care: each one singing hers, and this diversity of songs and voices caused a din of noise which were joined with the instruments, which were in as little agreement as the voices, making one want to laugh. They jumped and danced with so great a noise, which I believed similar to the Witches of Loudun, like they were possessed of some spirit or imp in a gay and jovial mood. But the time for surprise had not yet come. Silence followed the loud racket ... and a nun rose and sitting gravely in an armchair she began a long speech to the Assembly in corrupt Portuguese, such as that spoken by the slaves. This speech was a satirical recital of the gallant intrigues of the Officers of the Court of the Viceroy. It revealed the mistress of each one and cited her good and bad qualities.

[Eventually] there occurred a small incident ... and love wanted to play a role in the comedy. But in order to understand this scene, Sir, you must know that in Spain and Portugal, the soldiers are in love with the nuns, with whom they have devotional relationships. The nephew of the viceroy loved one of these nuns, but that love, so platonic, was not able to occupy all his heart, and he often looked for the more solid loves and occupations. The jealous nun did not want to hear reason and deprived of certain pleasures, she also wanted to deprive them of her lover. She chose that night to reproach him for his infidelity. The viceroy's nephew... little docile, accepted the reprimand badly and reddening in the face from the little bit of shame from his woman, he abruptly ran from the Church. ${ }^{35}$

Unbundling all of the subversive and contradictory elements of this passage would take more space than I am allotted here, but a few important points must be emphasized. The choreography of the performance was clearly aligned to calundu - the music and dancing to invoke the spirit, the silence invoked by the possession, and the 'corrupt Portuguese' of the spirit medium, who divined the illicit affairs of Bahia's wealthy and powerful. Barbinais compared the proceedings to the bewitched nuns of 'Loudun', a famous episode in French history, which perhaps not coincidentally is phonetically similar to lundu, the shortened version of calundu often used in Brazilian speech. ${ }^{36}$ Might the Frenchman have asked what was going on, and in response someone answered 'lundu', which then prompted his own francophone rendering? Most importantly, regardless of the farcical or comedic nature of the proceedings, the rituals in the convent revealed hidden truths, in much the same fashion as Angolan forms of divination. That the gathered assembly consisted of the wealthiest and most powerful in colonial Brazil only underscores the braided intellectual histories of Portuguese and African, high and low.

Thus, in Brazil's only convent, where roughly a third of the nuns were the daughters of sugar plantation owners, colonial officials gathered with soldiers, wealthy merchants, and foreign dignitaries to hear Christmas mass in $17 \mathrm{I} 7 .{ }^{37}$ But they also witnessed something

35 De La Barbinais Le Gentil, Nouveau voyage autour du monde [Texte imprimé], par Le Gentil, enrichi de plusieurs plans, vîüs et perspectives des principales villes et ports du Pérou, Chily, Brésil et de la Chine, avec une description de l'Empire de la Chine... T. 3 (Amsterdam, I728), I49-52.

36 The demonic possession of Ursuline nuns at Loudun was one of the most sensational witchcraft cases in recorded history and has been the subject of numerous books and films, including A. Huxley, The Devils of Loudun (New York, I952); and M. de Certeau, The Possession at Loudun (Chicago, 2000).

37 On the Santa Clara convent, see S. A. Soeiro, 'The social and economic role of the convent: women and nuns in colonial Bahia, I677-I800', Hispanic American Historical Review, 54:2 (I974), 209-32. 
distinctly Central African - the performance of calund $u$ by nuns, before the Brazilian colonial elite, with embarrassing outcomes, which were then recorded by a French witness and later published simultaneously in Paris and Amsterdam in $1728 .^{38}$ Barbinais could not have known it, but the calundu in the convent operated as a sort of resumé of the social order for all of colonial Brazil. The nuns drew upon the powers of lundus in order to offer sharp social critiques of colonial elites whose fragile sense of community was defined primarily by the Portuguese Crown and the Catholic Church. In some ways, these were the perfect individualized Western subjects - wealthy, male, literate, and politically connected. Yet the 'unspeakable' truth of these powerful men was that many were isolated and alone, prompting the breakdown in social values and norms. Though we might be tempted to interpret the revelations in the convent as a form of early psychiatry or group therapy, such 'modern' conclusions would obscure divination as the epistemological source of this hidden knowledge, and, in turn, erase the ontological domain of ancestral spirits from which that knowledge emanated. It was precisely through the unity of lundus and living kin that the 'sisters' could assert their authority and restore the Catholic colonial 'family'. In short, the ontological domain of lundus helped facilitate colonialism, even as it challenged the very bases of individual Western subjectivity. These are the delicious and entangled ironies of Atlantic history. Yet without an understanding of eighteenthcentury Angolan categories of knowledge and ways of being, the Barbinais description can be dismissed as little more than an odd, Portuguese 'farce', reifying the nuns as objects of Western alterity. ${ }^{39}$ With an African lens, rich, new possibilities are revealed, reversing our usual assumptions about colonial mimesis and the emergence of groups like 'Atlantic creoles'. Ultimately, only if scholars commit to a more serious and sustained engagement with African histories and ethno-graphic ways of being will Atlantic studies be able to move beyond European-American exceptionalism, beyond the 'slave', toward a more balanced historical rendering of the 'Atlantic'.

38 The Amsterdam edition appeared in the same year as the French edition, published in Paris ( 1728$)$.

39 In his Masters and the Slaves, Gilberto Freyre makes a passing reference to this description by Barbinais, essentially taking it at face value. Freyre notes that 'the sisters sang and danced and created such a hubbub as to lead the traveler to believe that they were possessed of scoffing demons. After which they performed a comedy of love.' G. Freyre, The Masters and the Slaves (Casa-grande of Senzala): A Study in the Development of Brazilian Civilization (New York, I956), 256. 